\title{
Islamic Ethos: Examining Sources of Authority
}

\section{Lana Oweidat}

Center for Contemporary and Creative Writing, Goucher College, Baltimore, MD 21204, USA;

lana.oweidat@goucher.edu

Received: 2 September 2019; Accepted: 17 October 2019; Published: 24 October 2019

check for updates

\begin{abstract}
This paper investigates the construction of Islamic ethos in the early Islamic period, highlighting what constitutes the guiding principles of its authority. As a religion that is currently subject to many ugly charges, a careful examination of its core historic values provides a counternarrative to the distorted ideology perpetuated by extremists such as The Islamic State of Iraq and Syria (ISIS), as well as to the Islamophobic and anti-Muslim racist discourse circulating in the West. The counternarrative presented here serves scholars of ethos whose expertise lies elsewhere than in religious studies. While providing this historical narrative, I highlight how Islamic ethos is derived from multiple sources of religious and cultural/communal authority, mainly from The Qur'an (the holy book of Muslims); the Sunnah (the Prophet Muhammad's example, deeds, and customs); and ijtihad (the interpretations and deductions of Muslim religious leaders). Tracing the construction of Islamic ethos through the creation of the Muslim community (Ummah) in $622 \mathrm{CE}$ and the establishment of the Caliphate in $632 \mathrm{CE}$ reveals guiding principles of conduct that are, in contrast to the discourses mentioned above, realistic, practical, and adaptable to current global needs and exigencies.
\end{abstract}

Keywords: Islamic ethos; nonwestern rhetorics; authority; Islamophobia; The Qur'an; Sunnah; Ijtihad; Islamic State; Muslim community (Ummah); Caliphate

\section{Introduction}

Islam today is undergoing a major crisis; it is under attack from extremists that commit atrocities in the name of Islam and from Western forces that perceive it as the enemy. The Arab Spring ${ }^{1}$ has let loose social forces that were subdued in the past by dictators or strong men of power. When these forces unleashed, Muslim-majority countries, such as Tunisia, Libya, Egypt, Syria, and Yemen, were thrown into political turmoil. The political authority in the pre-Arab Spring era in these Muslim-majority countries lacked a true democratic leadership. In the movement towards true democracy, demonstrations that varied in size and intensity swept these nations, overthrowing dictators or shaking their absolute authority. Among the forces that grew rapidly as a result of the political turmoil are extremist military groups, such as The Islamic State of Iraq and Levant (ISIL: alternatively ISIS, The Islamic State of Iraq and Syria). These groups invoke the Qur'an ${ }^{2}$ to justify military actions against civilians. The same tactic is used to recruit more militants. These groups aim at reverting to the model of the first Islamic community $(\text { Ummah })^{3}$ as established by Prophet Muhammad in 622 CE and the Caliphate installed after his death. However, the Quranic evidence these groups

1 The Arab Spring was a series of protests that happened across several Muslim-majority countries, such as Tunisia, Egypt, Libya, Morocco, and Syria beginning in 2010. Protesters called for the overthrow of dictators, the increase in democracy, and the improvement of living conditions-to name just a few demands.

2 A list of glossary terms can be found at the end of the article.

3 Fred Donner believes that the documentation prior to Ma'awiya ibn Abi Sufyan's reign (685-705 CE) is "too meager to permit firm conclusions" regarding the existence of a structured Islamic State at that time (Donner 1986, p. 283). Therefore, similar to the scholars I cite in my piece, I refer to the early Muslim community at the time of Prophet Muhammad as the 
employ is usually manipulated, fabricated, and taken out of context. Mark Townsend, Home Affairs Editor of The Observer, reports on the ISISI-produced book The Jurisprudence of Blood (Figh al-Dima) that is used to justify their barbaric, violent actions (Townsend 2018). Townsend gives special attention to the topic of "surrender vs. fighting to the death" that mandates jihadists to "choose death instead of handing themselves over to the enemy" (Townsend 2018). He then cites Islamic Studies scholar Sheikh Salah al-Ansari, who counters that "no religious requirement existed [in Islam] to 'fight to the death' and that the Islamic tradition of warfare encouraged the humane treatment of prisoners of war" (Townsend 2018). Like other Islamic scholars, Al-Ansari believes that ISIS tends to disregard the "traditional Islamic scholarship," and I add, they also neglect the Islamic interpretive tradition that developed over many centuries (Townsend 2018).

Muslims have been denouncing ISIS and its practices since its emergence, especially for its awful violations of human rights and women's rights, including through statements issued by Muslim leaders condemning ISIS and its practices and on social media through the \#NotInMyName campaign and other outlets (Bin Hassan 2016, p. 5). Although the Muslim world as a collective has distanced itself from ISIS, ISIS has had some success in promoting its "distorted version of Islam ... to the Muslim world" through "its propaganda machinery" that "promoted the religious legitimacy of its self-proclaimed Caliphate, as well as its offensive jihad, suicide bombings, 'lone-wolf' attacks, and brutal executions" (Bin Hassan 2016, p. 5). As for its treatment of women, The Counter Terrorism Project labels ISIS as an "anti-women ideology," as its practices towards women include rape, enslavement, forced marriages, social isolation, and forced covering, to name a few (ISIS's Persecution of Women 2017). While there are imperial forces working to increase the divide and the tension in that region, the current situation begs the question: Could this distorted interpretation of religious scriptures get more approval? How can Muslims work from within to create democracies that are in tandem with their belief systems? Could a deeper understanding of Islamic ethos and its roots play a role in how these questions are answered? Meanwhile, a collective guilt is undeservedly placed on the majority of Muslims, who do not approve of this association between Islam and radicalism. For most of the 1.6 billion Muslims in the world, Islam is compassionate, just, and capable of keeping up with the exigencies of time.

Religions, including Islam, are by their nature based upon oral traditions joined to the inner workings of faith; as such, they cannot always be traced to discernible, textual sources. However, an examination of the textual sources that do exist for Islam is particularly timely in the light of modern Western Islamophobia and anti-Muslim racism. In an era in which Islam is under attack and subject to many ugly charges, such as violence and dogmatism, a careful examination of Islam's collective, communitarian ethos reveals the inaccuracy of these charges. Contrary to the stereotypical image that prevails in Western media outlets, one of the main principles in Islam mandates that "Let there be no compulsion in religion" ${ }^{4}$ and that tolerance is highly valued (The Holy Qur'an 2000, 2:256). The Qur'anic ethics emphasize justice, care, compassion, and accountability. Yet this is not the narrative being heard in mainstream debate. This anti-Islamic sentiment creates a need to explore the guiding beliefs and principles of that religion.

In its historical, cultural, textual, and oral-traditional foundations, Islam is a communitarian religion and, as such, aims at neighborliness, equity, the protection of civil rights, and peace. The Qur'an as read, understood, and followed by this author is a Qur'an of peace. As contemporary conditions

"Muslim community" or "Muslim society" to emphasize that a form of structured community did exist. The era after the death of Prophet Muhammad is referred to as The Caliphate.

4 While I use this Qur'anic verse to indicate "the general command that people cannot be forced to convert to Islam," it is important to highlight, as Jonathan Brown has argued, that Qur'anic verses need to be understood in their own context (Brown 2015, p. 45). In other words, understanding the Qur'anic verses is contingent upon "grasping the specific circumstances of their revelation" (Brown 2015, p. 45). Brown explains that this specific verse was revealed when "a child of a Muslim family who had been educated in the town's Jewish schools" wanted to leave with "the Jewish tribe being expelled from Madina" (2015, p. 45). The verse was revealed to communicate to the parents that they "cannot compel their son to stay" (Brown 2015, p. 45). 
prove, what "is" and what "ought to be" are often at odds; in retelling this early history, I seek to articulate an ethotic foundation for exploring contemporary belief and practice: What Islam "is" in its early history allows us to ask important questions about what Islam "ought to be" today. In the narrative that follows, the ethos of Islam is explored through its Prophet and the first four caliphs. This essay seeks to outline the Qur'anic and the Sunnah practices of these ethical/ethotic terms, as they constitute the foundation of the Islamic tradition. In Islam, one's proper ethos is built upon the Qur'an preeminently and the Sunnah (Prophet Muhammad's example, deeds, and customs), which teach an ethos/ethics of justice, charity, and personal accountability.

This essay faces the problem of ethos from the start, not just for its subject, but for its author and reading audience. I write as a woman, an academician, and a scholar whose own ethos rests in Islam. I write of the early history and guiding principles of my faith, fully aware of questions my predominately non-Muslim readership is likely to bring to the text. Readers who call themselves scholars and/or critics of Islam will already know the early history sketched here and will have made up their minds. More modestly, this text aims to begin a conversation on Islam as narrative and ethotic discourse; it aims to serve scholars in cultural studies as well as in the varieties of composition and rhetoric, fields to which I have devoted my teaching and scholarship.

In their "Twenty-Five Years of Faith in Writing: Religion and Composition, 1992-2017," Paul Lynch and Matthew Miller invoke Stanley Fish's prediction that religion "is poised to join, if not replace, race, class, and gender as the central interests of humanistic inquiry" in the composition classroom (Lynch and Miller 2017, p. 3). Fish questioned whether academics "were ready" for this phase, arguing that we "should not construe religious students" unfairly (qtd. in Lynch and Miller 2017, p. 3). This call for promoting religious diversity in the composition classroom prompted Lynch and Miller to produce a bibliography on rhetoric and religion. While the Judeo-Christian tradition is heavily represented in the bibliography, the Islamic tradition, as the authors themselves have noticed, is woefully underrepresented. The scarcity of scholarship in the field about Islam and the Islamic rhetorical tradition is a gap that we should address. As Fish noted, it is time to prepare for a future where religion plays a significant role in the composition classroom and the field as a whole.

This piece responds to Lynch and Miller's recognition that Islam has yet to be included in our field's discussions of religion, rhetoric, ethos, and identity. I provide a historical account of the early Islamic period, the historical era in which Islamic ethos was fashioned. I highlight the major historical events, the ethical values, and the moral norms that reflect the character of this religion and its followers and present its religious and cultural authorities. Through the teachings of the Qur'an and the practices of Prophet Muhammad, I give special attention to his treatment of women and to the figure of Aisha, Prophet Muhammad's wife who lived through the early Islamic period. These challenge the Western stereotypical image of Muslim women as passive and submissive, disrupting the "anti-women ideology" perpetuated by ISIS. Through the investigation of its foundational values, I underline how the sense of ethos presented by Islam as a belief system and practice, embraces tolerance, justice, and inclusivity and is adaptable to cultural development, unlike the commonly held belief in the West and the practices propagated by ISIS.

\section{Early Islamic History: The Beginnings}

The story of Islam and the implications of its ethos are inseparable from the life of Prophet Muhammad, the last messenger of God (Allah) according to Islamic convention. The Prophet's mannerisms, behaviors, and actions persuaded people to follow God's commands and the Prophet's teachings, thus attracting them to the religion of Islam. Since his early years, Muhammad, an Arabic name which means "the highly praised," was a special young boy both in his character and in his demeanor. He was born into an Arabic tribe called Quraish in 571 CE. His early life was marked with a series of tragic events, from the death of his father when he was an infant to his mother's death a few years later, and then to his grandfather's passing when he was eight (Nasr 2001, p. 8). Being under the care of his uncle, Abu-Talib, after the death of his immediate family members, Muhammad 
had to work as a shepherd for his uncle's livestock; a task that he accomplished efficiently and to his uncle's satisfaction. This well-mannered young boy grew up to be a fine man whose community and family referred to as "The True," "The Upright," and "The Trustworthy One" (Nasr 2001, p. 8). These qualities grounded his ethos as a respectable, honest person. Through his reputation and credibility as a hardworking and trustworthy individual, many people within Muhammad's community decided to join the Islamic faith.

The story of the beginning of Islam as a faith goes back to the days when Muhammad used to enjoy his solitude in Ghar Hira (a cave located in Mecca). One day, he heard a voice commanding him to "read" and he answered, terrified, "I am not a reader." 5 Then, the voice of the Angel Gabriel mediated the first chapter (surah) of the Qur'an to Muhammad:

Proclaim! (or Read!) in the name of thy Lord and Cherisher, Who created-

Created man, out of a (mere) clot of congealed blood:

Proclaim! And thy Lord is Most Bountiful-

He Who taught (the use of) the Pen-

Taught man that which he knew not. (The Holy Qur'an 2000, 96:1-5)

The first revelation Prophet Muhammad received in 609 CE marked the beginning of Islam. Khadija, Prophet Muhammad's first wife and his senior of fifteen years, was the first person to believe in his message. Her constant support throughout his journey as a Prophet of Islam contributed significantly to the spread of the message of Islam. She was his trusted consultant, whose opinions were sought and taken seriously. This partnership presents an early indicator of the significant role women played in the early Islamic period, contrary to the image of Muslim women as voiceless and disempowered.

As Muslims' first and most important reference guide for conduct, morals, and behavior, within Qur'anic revelations, God speaks directly, in the first person, to the listeners of his words, making his laws and rules known to them (Nasr 2001, p. 29). Prophet Muhammad kept receiving these revelations for 23 years (609-32 CE). The early revelations stressed the oneness and uniqueness of God, rejecting polytheism and emphasizing man's moral responsibility; therefore, it challenged early pagan beliefs. Muslims have been relying on the Qur'an since it was revealed to Prophet Muhammad as a guide to living righteously; hence, it is the heart of Islam, and its significance as a source of ethos is hard to overstate.

\section{The Qur'an: The Main Source of Islamic Ethos}

In praising the Qur'an as a longstanding miracle, Prophet Muhammad says: "Do you ask for a greater miracle than this, $\mathrm{O}$ unbelieving people, than to have your language chosen as the language of that incomparable Book, one piece of which puts all your golden poetry to shame?" (qtd. in Ali 1891, p. 107). The Qur'an, which consists of 114 chapters (surah), is considered the most eloquent text in the Arabic language. While it is a complex, difficult book to read, even for native speakers of Arabic, it is a rhetorically sophisticated one. It is an ambiguous text that needs pondering, investigation, and delving into its mystery while keeping an open mind about its different interpretations and meanings. Lesley Hazleton, historian and author of The First Muslim, describes her plan to read the Qur'an in three weeks as hubris, as it took her three months to read it utilizing four well-known translations. She commented on the Qur'an's elusive nature as follows: "every time I thought I was beginning to get a handle on the Qur'an ... , it slipped away overnight" (Hazleton 2010). Although translated in multiple languages, the Qur'an, as many scholars agree, is meant to be read in Arabic. It is through this text that God's words are revealed to Muhammad, which makes it a key reference to God's commands and vision for Muslims.

5 Prophet Muhammad was illiterate (ummi). 
While the Qur'an stresses the communal ethos of Islam, it also emphasizes individuality. So we hear about the uniqueness of one's soul, and that "humans' fundamental nature is unalterably good, so they are entitled to self-respect and a healthy self-image" (Nasr 2001, p. 39). The Qur'an tells the story of the human self in its creation and, in its detailed description of the stages of fetal development, reveals knowledge that has only in recent centuries been scientifically discovered:

O mankind!... We created you out of dust, then out of sperm, then out of leechlike clot, then out of a morsel of flesh, partly formed and partly unformed, in order that we might manifest (Our power) to you; and We cause whom We will to rest in the wombs for an appointed term, then do We bring you out as babes... (The Holy Qur'an 2000, 22:5)

It is through this and similar revelations that Muslims perceive the Qur'an, not only as the longstanding miracle, but also as evidence of God's authority, power, and knowledge in which they trust. Islam, after all, is a religion that "centers on its religious Ultimate, God," one God that has no children and whose merciful and compassionate nature overshadows his anger and wrath (Nasr 2001, p. 33). And with this emphasis on the individuality of humans comes an ethos/ethics of accountability.

God sets the parameters for religious and social responsibility, duties, and accountability in the following verse: "It is not righteousness that you turn your faces towards the East and the West, but righteous is the one who believes in Allah, and the Last Day, and the angels and the Book and the prophets. These are they who are truthful; and these are they who keep their duty" (The Holy Qur'an 2000, 22:177). Every adult, mature, sane Muslim is responsible for their actions and held accountable. The Qur'an established a system of ruling that should be carried out by "men of integrity" that believe in consultation (shura); this system stresses the importance of holding those in charge accountable for their actions (Sowerwine 2009). Every Muslim should believe in the Day of Judgment where "every soul will be confronted with all the good it has done, and all the evil it has done, it will wish there were a great distance between it and its evil. But Allah cautions you (to fear) Him. And Allah is full of kindness to those that serve Him" (The Holy Qur'an 2000, 3:30). Muslims are not only held accountable for believing in God and the Day of Judgment, but also for caring for one's family and the needy in their communities.

The Qur'an advocates comprehensive measures to be adopted in this regard, making it a religious obligation: "And render to the kindred their due rights, as (also) to those in want, and to the wayfarer: but squander not (your wealth) in the manner of spendthrift" (The Holy Qur'an 2000, 17:26). The Qur'an includes many such verses, mandating Muslims to give compulsory charity (zakat) and encouraging them to give voluntary charity (sadaqah). According to Islamic law, zakat is to be used to support the poor and the needy, in addition to helping those in debt (and, in the past, it was used to free slaves). This compulsory charity (zakat), which was established fourteen hundred years ago, is considered one of the main pillars of Islam. Ibrahim B. Syed refers to the zakat as a "social security system of Islam [that] is Divine in character and based entirely on the Qur'an and Sunnah" (Syed n.d.). God makes a clear association between attaining righteousness and giving zakat as evidenced by this verse from the Qur'an: "By no means shall ye attain righteousness unless ye give (freely) of that which ye love; and whatever ye give, of a truth Allah knoweth it well" (The Holy Qur'an 2000, 3:92). As the Qur'an established guidelines for human interaction, balancing the collective ethos of the Muslim community (Ummah) with individual responsibility and moral authority, Prophet Muhammad's life and teachings further reinforced this Islamic ethos.

\section{The Journey Continues: Constructing an Ethos of Brotherhood and Community}

The Qur'an warns against hate, division, and disunity, urging Muslim believers to embrace an ethos of brotherhood that transcends all boundaries of race, culture, language, and tribal affiliations. As Prophet Muhammad was receiving the Qur'anic revelations, he was confronted with hostility from the residents of Mecca, including some of his own family and tribe (Nasr 2001, p. 15). After a decade of constant harassment, Muhammad and his followers planned their migration to Madina in $622 \mathrm{CE}$, 
where they were welcomed by supporters (Al-Ansar). This migration marked a new phase in the history of early Islam as the organizational structure of the community became focused on "brotherhood" rather than on kinship. The brotherhood for which Islam calls entails love for one's brother in the same way one loves one's self. Prophet Muhammad said: "By the One in Whose Hand is my soul, you will not enter Paradise until you believe, and you will not believe until you love one another. Shall I not tell you of something which, if you do it, you will love one another? Spread (the greeting of) peace among yourselves" (Muslim 1330 CE, 5: 33: 3672). As Islam reinforced an ethos of brotherhood, the attention was on creating unity in diversity within the Islamic society (Sajoo 1995, p. 582) where, in the words of Prophet Muhammad, "there is no superiority for an Arab over a non-Arab and for a non-Arab over an Arab, nor for the white over the black nor for the black over the white except in piety" (Asfahani n.d., p. 100). ${ }^{6}$ This approach materialized in the implantation of a civil code called the "Constitution of Madina," a formal agreement between Prophet Muhammad and the tribes and the residents of Madina, including Jews, Christians, and pagans (Sajoo 1995, p. 582). Governed by the Constitution of Madina, the first Islamic community was established in 622 CE.

The establishment of this community, as Suhail M. Hashmi argues, was "foundation not just to Islamic history, but also to Islamic ethics. Islam would be henceforth both a religion (in the sense of a theological system) as well as an earthly community" (Hashmi 2007, p. 7). This Muslim community (Ummah) created a sense of unity, which transformed after the Prophet's death by his disciples into a Caliphate (632-661 CE). This civil code that governed the first Islamic society is "one of the best examples to understand the importance of peace, security, and interfaith in the religion of Islam" (Tahir-ul-Qadri 2012, p. 1). It included sixty-three articles that controlled and managed the relationship between Prophet Muhammad and his followers on the one hand and the tribes of Madina on the other hand. Reflecting the Qur'an's sentiment of interfaith dialogue and respecting religious difference, this constitution established religious freedom for non-Muslims, stressed the security of the community, created a tax system to support the community during war time, laid out the rules for political alliances, and established a judicial system for conflict management (Tahir-ul-Qadri 2012, p. 2). During this period, Muslims defended themselves against the atrocities of Meccans in different battles, including Badr (625 CE), Uhud (625 CE), and The Trench (627 CE). This is not to contradict the notion of the peaceful message of Islam, as evident in many verses of the Qur'an, such as "But if the enemy include towards peace, do thou (also) incline towards peace, and trust in Allah: for He is the One that hearth and knoweth (all things)," but to emphasize the practicality of Islam's guiding principles (The Holy Qur'an 2000, 8:61). ${ }^{7}$ As such, violence is deemed necessary in some cases, including in self-defense.

Unlike the commonly held belief by non-Muslims (and perhaps some Muslims as well) that jihad means "holy war," war in Islam "was always regarded as a necessary evil but never holy or sacred" (Omar 2011, p. 708). The word jihad means "to strive" in all matters. Jihad, as Irfan A. Omar notes, "is striving, discernment, and reflection" (Omar 2011, p. 708). When this striving took a military form, it was usually out of self-defense (the need to defend the followers of Muhammad) or to guarantee the survival of their faith. There are multiple examples from Prophet Muhammad's life (seerah) that encouraged a peaceful form of jihad. Jihad against one's self (Jihad al-nafs) is the greatest form of Jihad, as it emphasizes a person's spiritual and moral self-struggle (Ali and Rehman 2005, p. 330). This form of jihad entails constant reflection and self-examination and is thus perceived as being at a higher level than other forms of jihad. The emphasis on exerting one's effort to the maximum of one's capability is echoed in the Prophet Muhammad's attention to the importance of striving for social justice and speaking truth to power. When asked about the best form of jihad, Prophet Muhammad responded: "A word of truth spoken before an unjust ruler" (An-Nasa'i n.d., 15: 39: 4214).

6 Al-Asfahani (948-1038 CE).

7 The title of the translation I am using is The Holy Qur'an, which is a direct translation of the Qur'an-the holy book of Muslims. 
When engaged in military jihad, Prophet Muhammad made sure to follow the Qur'an's war ethics and teach them to his followers. Following Prophet Muhammad's teachings, Abu Bakr, Prophet Muhammad's companion and the first caliph of Islam, laid out guiding principles for engaging in battle:

O people! I charge you with ten rules; learn them well! Stop, O people, that I may give you ten rules for your guidance in the battlefield. Do not commit treachery or deviate from the right path. You must not mutilate dead bodies. Neither kill a child, nor a woman, nor an aged man. Bring no harm to the trees, nor burn them with fire, especially those which are fruitful. Slay not any of the enemy's flock, save for your food. You are likely to pass by people who have devoted their lives to monastic services; leave them alone. (qtd. in Ali and Rehman 2005, p. 341 $)^{8}$

The teachings of Islam set the guidelines for tolerant, forgiving, environmentally aware military regulations. These civil guidelines, as Ali and Rehman argue, are in agreement with the regulations of modern international law (Ali and Rehman 2005, p. 345). The Islamic ethos of civility and kindness combined with firmness and authority reflects not only the nature of Islam, but also the sophistication of Prophet Muhammad's leadership. He was a leader capable of exercising power and authority while maintaining his merciful and kind nature. Additionally, his leadership emphasized the importance of implementing a model of consultation (shura) as directed in the Qur'an, in which he consulted his companions about matters related to the Muslim community (Ummah), while he had the final authority. Leaders of the community succeeding Prophet Muhammad continued to use this consultative model of leadership to help them to make decisions. As this community gained more strength, Prophet Muhammad returned to Mecca and expanded the territory, spreading the message of Islam to different parts of the world. The first community established in Madina functioned as "a model of the virtuous Muslim polity in the following centuries, long after the Islamic state had become a polyglot empire extending over three continents" (Hashmi 2007, p. 6). This expansion, as Sohail H. Hashmi has argued, stems from the "conviction that Muslims were bound to spread the Islamic order universally-through peaceful means if possible, through forceful means if necessary" (Hashmi 2007, p. 6).

The political agenda of protecting the first Islamic society and strengthening its fabric from within occupied Prophet Muhammad and his followers at that time. This complicates our ability to apply early Islamic rulers as some sort of paradigms for today. It is worth noting, however, that Professor Paul Freedman emphasizes that Muslim territorial expansion has to be "understood in terms of religious motivation but not in terms of a determination to wipe out Judaism and Christianity," as "there was not a demand for the conversion of the population to Islam" (Freedman 2011). Although the conversion does happen in the conquered regions, "it does not take place immediately ... nor under great pressure" (Freedman 2011). In other words, according to Freedman, "the motivation provided by the religion to conquer does not necessarily mean that you require everybody you conquer to embrace the religion" (Freedman 2011). While the early Muslim leaders were respectful of other religions in the conquered areas, ISIS's treatment of non-Muslims has been described "by the international community as genocide and crimes against humanity" (ISIS's Persecution of Religions 2017). For ISIS, non-Muslims either convert to Islam or get killed. Even when Muslims engaged in territorial expansion in the early Islamic period, there is strong evidence to support that they believed in peaceful co-existence rather than violently forced conversion.

The Muslim community valued unity in diversity as it embraced non-Muslims in the conquered regions, such as Christians and Jews, and referred to them as the "People of the Book" (Ahl Al-kitab). As this sense of community strengthened under Prophet Muhammad's leadership, ethnic allegiances

8 According to the footnote provided by Ali \& Rehman, the original Arabic text appears in Al-Tabari's The History of the Prophets and Kings (923 CE). It was quoted and translated by Majid Khuddari in his book The Islamic Law of Nations (1966). While the ten rules are mentioned in the Arabic text, a couple of points were combined for ease of translation in Khuddari's translated text. 
became less prominent. The "People of the Book" (Ahl Al-kitab) were granted the status of a dihimmi, which entailed protection for their "life, body, and property, as well as freedom of movement and religious practice" (Martin 2004, p. 451). In return for this protection, they had to pay a tax (Jizya). The status of the dhimmis "was secured by a legal institution called dhimma ('protection')" (Martin 2004, p. 451). There are several examples in the life of Prophet Muhammad (seerah) that exemplify his tolerance and kindness to non-Muslims-from exchanging gifts with his non-Muslim neighbors, to doing business with non-Muslims, and visiting them when they were not feeling well. For example, there was a Jewish family in particular that he supported by giving charity to and his successors kept the same tradition after his death (At-Tahan 1999).

This acceptance, even concern, for others was not limited to those of differing faiths, as Prophet Muhammad also always considered the condition of women and defended women's status. In an era where women were treated as second-class citizens, he revolutionized the status of women. His example stands in complete contradiction to the current practices against women performed by ISIS and other Islamic fundamentalist groups and even the ones practiced in some Muslim-majority countries.

\section{Women's Ethos in the Early Islamic Period: The Case of Aisha}

As the Muslim world faces new challenges from extremist groups that call for undermining women's agency and suppressing their rights in the name of Islam, examining Prophet Muhammad's treatment of women in the early Islamic period reveals the contradiction of ISIS's message. Islam abolished the practice of infanticide, granted property rights for women by inheritance, gave women the right to divorce, and made men and women equal in the sight of God, as emphasized in the Qur'an: "Whoever works righteousness, man or woman, and has Faith, verily, to him will We give a new Life, a life that is good and pure; and We will bestow on such their reward according to the best of their actions" (The Holy Qur'an 2000, 16:97). These rights which stem mainly from the teachings of the Qur'an were reinforced by Prophet's Muhammad's Sunnah. ${ }^{9}$ Although there are many female figures in the early Islamic period that would provide a counter narrative to the "anti-woman ideology" perpetuated by extremist groups, including Khadija, Umm Waraqah, and Asma Bint Abi Bakr, my attention will be geared towards Aisha (612-678 AD)_Prophet Muhammad's most beloved wife and the daughter of Abu Bakr, the first Caliph in Islam.

Aisha played a significant role, both during Prophet Muhammad's life and after his death, in the development and understanding of the Islamic faith through the multiple hats she wore as a partner, companion, political leader, transmitter of hadith ${ }^{10}$ and scholar. Additionally, the examination of Aisha's figure problematizes the patriarchal authority that characterizes Abrahamic religions. A few scholars have given her attention in the past few years; however, with the West's current imperial rhetoric of saving brown women from brown men, ${ }^{11}$ Aisha emerges as an important figure that challenges the stereotypical image of Muslim women as passive and submissive.

\subsection{The Wife and "Mother of Believers"}

As a wife, Aisha occupied a special place in Prophet Muhammad's life. Many Muslims perceive this relationship as a loving, egalitarian marriage in which both parties had great love and respect for one another. Islamic historians provide some examples that testify to the bond they shared. Prophet Muhammad raced with Aisha, humored her, and had long conversations with her (Muslim 1330 CE, 9: 2055). In addition, they used to drink from the same cup and eat from the same plate (Muslim 1330

9 Sunnah refers to Prophet Muhammad's actions, sayings, behaviors, personality traits, gestures, and descriptions as recorded by his companions.

10 Hadith refers to the body of knowledge about Prophet Muhammad that was reported by his companions.

11 I am referring here to the women of Iraq and Afghanistan, who are mainly Muslim women. The notion of "saving brown women from brown men" has been utilized by many postcolonial scholars, such as Gayatri Spivak, to highlight how the colonizer has used the excuse of saving brown women to justify colonial interventions (Spivak 1994, p. 93). 
CE, 1: 283). This affection is also manifested in the discussions they had, which depict Aisha as a sophisticated conversation partner:

Aisha narrated that Muhammad described his love to her like a knot firmly tied on a rope. Aisha used to ask Muhammad from time to time 'how is the knot' and Muhammad used to confirm his love to her. He said: 'The knot is still tied as firmly as it used to be' (qtd. in The Prophet of Islam Muhammad 2017).

In another incident that reflects Prophet Muhammad's love for Aisha and her place in his life, Aisha says: "'While the Ethiopians were playing with their small spears, Allah's Messenger screened me behind him and I watched (that display) and kept on watching till I left on my own.' So you may estimate of what age a little girl may listen to amusement" (Al-Bukhari 846 CE, 7: 62: 118).

Although these stories provide compelling evidence to the mutual love and trust between Aisha and Prophet Muhammad, Aisha's role as a wife to Prophet Muhammad goes beyond her dedication to her husband, as she was part of a community called "The Mothers of Believers," which consisted of Prophet Muhammad's wives. ${ }^{12}$ The Qur'an states: "The Prophet is closer to the Believers than their own selves, and his wives are their mothers" (The Holy Qur'an 2000, 33:6). Moreover, the Qur'an addresses Prophet Muhammad's wives directly, requiring them to "remember what is recited in your houses of God's revelation and wisdom" (The Holy Qur'an 2000, 33:34). It is worth mentioning that, as Aisha Geissinger has stated, "Muhammad's wives are the only group among his followers to which such an injunction is specifically directed in the quranic text" (Geissinger 2011, p. 37). The preservation of the Quranic text was the main task allotted to them, which was not easy given that they had to resort to memory for the preservation of the Qur'an in an era in which Prophet Muhammad and his followers faced tremendous resistance from their community. The Qur'an does not only dedicate certain responsibilities to the Mothers of Believers but makes them active contributors and participants in the aid of the Prophet's mission. The communal authority that her positioning brought about as one of the Mothers of Believers required that Aisha had to live up to God's, Prophet Muhammad's, and the Islamic community's expectations, serving as one of the guardians for the Qur'an (Geissinger 2011, p. 37).

\subsection{The Scholar and Transmitter of Islamic Religious Knowledge}

Another means in which Aisha preserved and served the Islamic faith was by transmitting hadith. Leila Ahmed argues that the examination of Aisha's figure within the Islamic context reveals the importance of her role in preserving the verbal text of Islam after the death of Prophet Muhammad (Ahmed 1992, p. 47). Although mainly characterized as a patriarchal society, the early Islamic society and its cultural norms were accepting of women in leading roles, which facilitated accepting Aisha as a religious authority (Ahmed 1992, p. 47). Aisha's testimonies and observations are crucial to Islam, since she had access to Prophet Muhammad's private life and was there observing, recording his actions, behaviors, gestures, and words. Aisha transmitted over 1000 hadith on a range of matters, including legal, ritual, and theological issues (Geissinger 2011, p. 41). Although her role as a transmitter of information was crucial, Aisha's own judgment on matters of marriage and divorce contributed to affirming her religious authority. Women felt comfortable sharing their stories, experiences, and problems, especially situations related to marriage. One day, a woman whose father was intending to force her into a marriage came to Aisha, complaining to her about the situation. Aisha told the Prophet, who, in turn, invited the father over for a discussion, in which the Prophet addressed indirectly the issue of forced marriages and emphasized that it was up to the woman to marry the person of her choice (Muslim 1330 CE, 4: 26: 3265). Such incidents testify not only to the trust and the knowledge of

12 Prophet Muhammad was single until he accepted Khadija's, his first wife's, proposal to marry her at the age of 25. She died when he was 50 . He married all his other wives between the ages of 5-60 for multiple reasons. These reasons were mainly relevant to his duty to deliver the message of the Islamic faith to the world. 
the religious Islamic rules and familiarity with the religious discourse that Aisha possessed, but also to her status as a confidant to many women and a trustworthy judge in their situations.

Aisha did not take anything at face value. Even when Prophet Muhammad was alive, she used to inquire and question everything, asking questions until she was satisfied with his answers. Her eagerness to learn and her intellectual curiosity allowed her to gain a respectable status as a scholar. It is due to this curiosity that, as the Islamic scholar Hakim said, "one-fourth of the body of religious knowledge" has been transferred to us (Tahmaz 1999, p. 174). Her reputation as the most knowledgeable religious scholar of her time is echoed in more than one testimony. Zurarah bin Awfa, the judge of Al-Basrah back then, narrated that he was told that Aisha was the most knowledgeable person on earth (An-Nasa'i n.d., 2: 20: 1722).

Prophet Muhammad's commitment to ensuring the status of women in Islam was evident in his treatment of women throughout his life. Abu Huraira ${ }^{13}$ reported Prophet Muhammad saying: "Act kindly towards women" (Muslim 1330 CE, 8: 3468). His respect and concern for women was also indicated when he requested to spend his last days with Aisha, dying in her lap, leaving behind a dynamic state whose ethos was reflected in the teachings of the Islamic religion that emphasized equity and care.

\section{The Ruling of the Caliphs}

The leadership of the Islamic society post Prophet Muhammad's death continued to be held by wise, honorable, and trustworthy men - qualities of phronesis, arete, and eunoia associated with classical Aristotelian ethos. The period of the ruling of the caliphs started from the death of the Prophet in $632 \mathrm{CE}$ and lasted through $661 \mathrm{CE}$. Prophet Muhammad's ethos of consultation (shura) continued to be employed in the political discourse after his death through the election of Muslim leaders. Islam emphasizes the importance of obeying leaders within the parameters of God's commands. Therefore, the leader's actions should be in accordance with Islamic law. According to the Qur'an, a leader should be an adult, sane, devout Muslim "with superior ethical character" and should be known for wisdom, God consciousness (taqwa), integrity, compassion, consultation (shura), honesty, justice, kindness, forgiveness, trustworthiness, and sense of responsibility (Akhter 2009, p. 127). As a person who had these qualities, Abu Bakr Al-Siddiq was the perfect candidate to lead the Islamic state at that time. The tension created around the succession of Prophet Muhammad led to the divide between Sunni and Shia Muslims, as the Prophet's companions were advocating for Abu Bakr, while the Prophet's tribe was rooting for Ali bin Abi-Talib, the cousin of Prophet Muhammad, on the basis of kinship (Hashmi 2007, pp. 11-12). Although Prophet Muhammad did not appoint a successor, his actions in the last days before his death insinuated that his preference was for Abu Bakr Al-Siddiq, as he told Aisha to "order Abu Bakr to lead the people in prayer" (Al-Bukhari 846 CE, 7: 62: 118). Islamic studies scholars, such as Wilfred Madelung, point to this particular hadith to suggest Prophet Muhammad's preference for Abu Bakr to be his successor (Madelung 1997, p. 1). The excerpt is from a hadith that is considered mutawatir, meaning it has the "highest classification of a tradition in hadith criticism," and is characterized by "an established series of transmitters (isnad), at least two per generation, all of whom are deemed reliable" (Esposito 2003). This process "ensures that the tradition is not fabricated" (Esposito 2003). Therefore, for Sunni Muslims, this piece of evidence strongly suggests Prophet Muhammad's support for Abu Bakr to be his successor. This gesture, in addition to his close association with the Prophet and his piety, played a significant role in the election of Abu Bakr as Prophet Muhammad's successor (Sowerwine 2009).

During the ruling of Abu Bakr, which lasted twenty-seven months, he subdued the tribal oppositions in Mecca and expanded the Islamic territory to include central Arabia (Madelung 1997, p. 45). In his first speech after his election, he said:

13 Sunni Muslims consider Abu Huraira the most prolific narrator of hadith. 
Behold! I have been charged with the responsibilities of government. I am not the best among you. I shall need all the advice and help that you can give. If I act well, you must support me. If I make a mistake, advise me ... To tell the truth to him who is given the responsibility to rule is dutiful allegiance. To hide would be treason. (qtd. in McIntire and Burns 2009, p. 81)

This speech aims to establish the ethos of an Islamic leader, whose first requisite is humility. Abu Bakr reminds Muslims that it is their duty to provide advice for their leader and to correct him if he digresses from God's instructions and the teachings of Prophet Muhammad. This emphasis on correcting the wrongs is also echoed in a hadith by Prophet Muhammad: "Whoever among you sees an evil, let him change it with his hand; if he cannot, then with his tongue; if he cannot, then with his heart- and that is the weakest of Faith'" (Muslim 1330 CE, 6: 47: 5011). This acknowledgment of the different individual capabilities provides those incapable physically or verbally of changing evil with the reassurance that they can fulfill that moral obligation with their hearts.

Although Islamic ethos can give the impression that it stems only from sacred texts, it can be "man-made," in the sense that qualified scholars can resolve issues that are not addressed in the Qur'an or the teachings of the Prophet (Sunnah). As the Islamic society expanded to include Mesopotamia, its leadership continued to promote just and humane values derived from God's commands and the Prophet's teachings. However, in order to keep up with changing conditions and the emergence of new issues, Muslims employ "independent reasoning" (ijtihad). There is a clear indication that when direct guidance from these two sources is lacking, exercising one's own judgment is key. This process of deriving regulations from the main Islamic sources of authority "may not contradict the Qur'an, and it may not be used in cases where consensus" has been reached along scholars (Esposito 2003). Ijtihad in Islam is "a matter of obligation for every able Muslim at the personal level" (Sajoo 1995, p. 581). While Islamic law stems primarily from the Qur'an and the teachings of Prophet Muhammad, it was "constructed by jurists in assorted locales beginning around $750 \mathrm{CE}$ over a century after the demise of the Prophet" (Sajoo 1995, p. 581). This body of knowledge is not a one-size-fits-all model, as it varies based on the school one follows. ${ }^{14}$

According to Abu Al-Hasan Al-Basri, a pious Islamic scholar (mujtahid, a person who practices ijtihad) should have certain qualifications to practice ijtihad, including having a moral, reliable ethos as a person and a scholar; being familiar with the Arabic language and with the Qur'an and Sunnah; capable of exercising logic and good reasoning; and must follow the consensus of past scholars (ijma') and have the skill to use analogic or syllogistic reasoning (qiyas) (Kamali 1991, p. 374). After the death of Prophet Muhammad, ijtihad was practiced by his companions, who were considered trustworthy, pious Muslims, and "had the good fortune to acquire proficiency in jurisprudence and legislation under [Prophet Muhammad's] guidance and they had recourse to the process or exercise of Ijtihad when a need arose in his absence" (Masood n.d.). One example of this would be when both Fatma bit Abi Bakr, one of Prophet Muhammad's wives, and Al-Abbas, the Prophet's uncle, requested their inheritance from what Prophet Muhammad had left behind. Abu Bakr, one of the Prophet's companions and the caliph of Muslims back then, denied their request based on a hadith saying that Prophets' families do not receive inheritance, and that what prophets leave behind should be given to charity.

Since the death of Prophet Muhammad until the present, Islamic scholars have been practicing independent reasoning (ijtihad), following consensus of past scholars (ijma'), and using analogic or syllogistic reasoning (qiyas) to provide answers to religious and legal questions. An example of "consultative ijtihad" would be the appointment of Omar Ibn Al-Khattab as the next Caliph of Islam (Kausar 2017, p. 156). Abu Bakr "was performing ijtihad in this matter," as his decision to nominate

14 There are four main schools that constitute the Sunni Muslim Shari'a law named after their founders: Hanafi, Shaf'i, Maliki, and Hanbali (Sajoo 1995, p. 581). While Sunni Muslims gather around these four schools, Shi'i Muslims have a more restrictive approach to ijtihad (Sajoo 1995, p. 581). The Jafari School emerged as the leading school of Shi'a Muslims in the eighth century, and since then, religious leaders (imams) have been providing guidance in religious matters that are not addressed in the Qur'an and Sunnah (Sajoo 1995, p. 581). 
Omar for this position was not a random one but based on reasoning and rationalization. The process started by considering who would be most appropriate to lead the Muslim community (Ummah) during that time and "whose leadership would be acceptable" to the Muslim community (Kausar 2017, p. 156). Secondly, Abu Bakr consulted with those who were potential candidates for this leadership position (Kausar 2017, p. 156). While the majority were in agreement that Omar would be a good choice, a concern was voiced regarding Omar's temperament (Kausar 2017, p. 156). Abu Bakr's judgment on this point was that this could provide a beneficial counterbalance to his own style of leadership, as he himself tended to be lenient (Kausar 2017, p. 156). After careful reflection and evaluation, Abu Bakr reached the conclusion that Omar would be the most appropriate person to hold his position (Kausar 2017, p. 156). Not only does this form of deductive reasoning mark Islamic ethos as realistic, practical, and capable of keeping up with the emerging issues of society; it also provides Muslims with a body of reliable propositions to help them to lead their lives within the parameters of the teachings of Islam.

This attention to deductive reasoning was a priority for the next successor, Omar Ibn Al-Khattab. A man well-known for his justice, firmness, and humility, Omar further reinforced Islamic ethos of social justice by judging with fairness and abolishing hierarchies. His famous saying, "Since when have you turned men into slaves, whereas they are born free of their mothers?" is among the most celebrated quotes about justice in the Islamic tradition (qtd. in Wirba 2017, p. 73).

As a sophisticated leader, he created "a police to maintain law and order, a welfare service to assist the needy, an education department, and a consultative body to deliberate on public policy and guide him in its implementation" (Griffiths 2005, p. 465). He used to walk the streets looking for poor people to feed, believing God would punish him if there was a needy person to whom he did not attend. A Roman messenger saw him sleeping under a tree when he uttered his famous praise of Omar's leadership: "O Omar! You ruled. You were just. Thus you were safe. And thus you slept" (qtd. in Ahmed 2000, p. 35). The point being that because of his justness and his clean consciousness, he was able to sleep under a tree without any protection. Though a military power under Omar's reign, the Islamic army abided by a set of rules and regulations that dictated causing the minimal amount of harm. Likewise, while great attention was geared towards justice, equity, and care for all individuals, the communal ethos of consultation (shura) was prominent throughout the period of the early Caliphs, especially during the reign of Omar. When the time came to find a successor for Omar, he appointed six men and charged them to elect a Caliph out of themselves (Sowerwine 2009). After long deliberations, the electoral committee decided in favor of Othman bin Affan.

In its emphasis upon charity and attending to the needy, the ethos of Islam incorporated justice with a communitarian sense of care that continued throughout the rule of the third Caliph Othman bin Affan, the son of a wealthy merchant, who put his money in the service of the Islamic community and the good of the people. Every week he would buy and set slaves free, and "although he was wealthy he was often without servants because of this habit" (Stacey 2009). Othman focused on building the army, corresponding with governors across the Islamic territory, and unifying Muslims from different ethnic and cultural backgrounds while respecting their differences. As more people were converting to Islam, he had concerns about preserving the Qur'an, so he tasked a committee to produce a standard copy of the Qur'an, make copies from it, and distribute it to all Islamic regions (Stacey 2009).

After the assassination of Othman by rebels, the electoral body assembled and elected Ali bin Abi-Talib, who ruled from 656 to 661, as the fourth caliph of Islam. Ali, the cousin of Prophet Muhammad, is known for ruling with equality and justice, especially in the distribution of taxes (Netton 2008, p. 105). However, he faced many challenges as he was engaged in more than one civil war during his rule. Ali was a central figure in the Sunni/Shia division (Netton 2008, p. 105). As mentioned earlier, Shia Muslims believe that the Prophet Muhammad appointed him as his successor and that Prophet Muhammad's family (ahl al-bayt) should occupy the leadership positions within the Islamic society. Sunni Muslims, however, believe that Prophet Muhammad did not appoint anyone to be his successor and left this issue up to his companions to delegate among themselves (Madelung 1997, p. 119). The battle of Siffin in which Ali fought against the governor of Syria, Mo'awya, resulted in a 
disastrous outcome for Ali as he had to step down from the caliphate (Netton 2008, p. 44). He was later assassinated in Kufa in Iraq.

This brief history of the creation of the first Islamic society reveals the roles that Prophet Muhammad and his companions played in the construction of Islamic ethos, an ethos that is socially, politically, and morally committed to the message and the teachings of Islam. While Prophet Muhammad's actions were influenced by the Qur'an-the teachings of God-his companions had the privilege of observing him closely and learning from him first-hand how to manage people with compassion and care.

\section{Past, Present, and Future of Islamic Ethos}

According to Islamic scholars, Islamic law is derived from three main sources that constitute the cultural and religious authorities of Islamic ethos: The Qur'an, The Sunnah, and independent reasoning (ijtihad). Although the Islamic ethos might be perceived as rigid in obedience to and enforcement of Islamic law, a careful pondering of the discourses that constitute this ethos reveals a significant call for thought and consideration. The Qur'an, as Ziauddin Sardar, has noted, is "generously sprinkled with references to thought and learning, reflection and reason." The holy book of Muslims "denounces those who do not use their critical faculties in strongest terms" (Sardar n.d.). The Qur'an makes it clear that " ... the worst of beasts in the sight of Allah are the deaf and the dumb-those who understand not" (The Holy Book 2000, 8:22). The Qur'an encourages critical thinking, which as many scholars, such as Sardar, have argued, is a faculty that "has been central to Islam from its inception" (Sardar n.d.). Prophet Muhammad's Sunnah has been instrumental in establishing a religion that advocates for the equitable treatment of people, especially women. Additionally, the weight given to logic and reason within Islamic ethos was evidenced in multiple ways: through the process of selecting the early Caliphs, the attention to consultation (shura), and independent reasoning (ijtihad), as well as to considering the consensus of past scholars (ijma') and using analogic or syllogistic reasoning (qiyas) to provide answers to religious and legal questions.

These discourses have been providing moral and ethical guidelines for Muslims since the time of Prophet Muhammad. In addition to governing the behaviors of Muslims around the world, they reflect the ideology inherent in Islam as a religion whose ethos is tolerant and adaptive to change-one that values human agency and individuality while holding Muslims accountable for their words and actions. Although this historical overview of Islamic ethos shows the difficult path Prophet Muhammad and his followers faced in preserving and spreading the message of Islam, the current social and political forces surrounding Islam present a different set of challenges as extremist military groups have pursued violence and oppression through a distorted ideological lens. However, this ethos does not perceive compassion and care in contradiction to reasoning but as complementary to it. Unlike the way ISIS portrays their strength through embracing violence and intolerance, the righteous believers in Islam, according to the Qur'an and the Sunnah, are the ones who demonstrate patience and suppress anger-those who are equitable, just, and forgiving.

These parameters for ethical conduct and moral character for Muslims show how the early leaders of Islam constructed an ethos that is just and adaptable-one that emphasizes compassion and accountability for all, regardless of gender or race. This examination of the construction of the early Muslim community and the rules of conduct that they abided by functions as a corrective to ISIS-like militant discourses that perpetuate violence and intolerance and as a disruptive tool to Western Islamophobia and anti-Muslim prejudice.

The examination I provide in this piece of the construction of Islamic ethos in the early Islamic period allows scholars and students to explore how this ethotic foundation relates to contemporary belief and practice. However, it can also help us to better understand and invite students into the rhetorical work taking place in our classrooms. As scholars and educators, we need to be mindful of how we and our students are situated and are functioning within rhetorical, racist discourses of anti-Muslim prejudice. We should be, as Stanely Fish indicates, "ready" for the discussion of religion in our classrooms. It is not a choice anymore for us "not to be ready," not if we are to build and 
encourage ethical engagement with difference, of which religious background can be a major factor. Scholars in different areas have been offering theoretical and pedagogical insights into engaging students about identity issues in ways that problematize their automatic conformity to systems of oppression. Disrupting stereotypes associated with Muslims is not insignificant-stereotypes are not superficial; they are the outcome of multiple discourses at work, as they "represent significant ways in which and through which students know, approach, and attempt to understand one another" (Alexander 2008, p. 139). Therefore, the discussion of religion and religious ethos is timely as it is at the heart of the rhetorics of the clash of civilizations, the war on terror, and the remobilization of Islamophobia. These discourses are currently being used as a means for justifying major political actions against Muslim-majority countries and Muslims in different parts of the world. Engaging with Islam's religious ethos can be a first step for students in multiple humanities disciplines toward reworking these discourses in a way that benefits both Muslim and non-Muslim students. For the former, it can make them feel welcomed in the academic sphere while helping them to better understand issues surrounding their identities and the forces influencing their construction. For the latter, it can problematize ingrained racisms and make for ethical, rather than potentially problematic, engagement with Muslims around the world.

Funding: This research received no external funding.

Acknowledgments: I would like to express my gratitude to the special issue editors and the peer reviewers for their insightful comments and feedback. I also wish to thank the journal's editors and staff for their time, effort, and support.

Conflicts of Interest: The author declares no conflict of interest.

\section{Glossary}

$\begin{array}{ll}\text { Ahl Al-bayt } & \text { Prophet Muhammad's family } \\ \text { Ahl Al-kitab } & \text { The "People of the Book;" the groups of people that were given holy books. The general } \\ \text { Al-Ansar } & \text { understanding is that they are Jews and Christians } \\ \text { Allah } & \text { Christians who supported prophet Muhammad } \\ \text { Dhimmi } & \text { A nod } \\ \text { Ijma' } & \text { The consensus of scholars } \\ \text { Ijtihad } & \text { Interpretations and deductions of Muslim religious leaders } \\ \text { Jihad } & \text { To strive in all matters } \\ \text { Jizya } & \text { A tax collected from non-Muslims who used to live under Islamic rule in the past as part } \\ \text { Mujtahid } & \text { of an agreement } \\ \text { Mutawatir } & \text { A person who practices ijtihad } \\ \text { Qiyas } & \text { A hadith is considered mutawatir when reported by a number of narrators } \\ \text { Sadaqah } & \text { Analogic or syllogistic reasoning } \\ \text { Sanad or isnad } & \text { Voluntary charity } \\ \text { Seerah } & \text { Chain of narration and authority } \\ \text { Shari'a } & \text { Prophet Muhammad's life } \\ \text { Shura } & \text { Religious law stemming from the multiple sources of authority: the Qur'an, Sunnah, and } \\ \text { Sunnah } & \text { Ijtihad (reasoning) } \\ \text { Surah } & \text { Consultation } \\ \text { Taqwa } & \text { The Prophet Muhammad's example, deeds, and customs } \\ \text { The Qur'an } & \text { A chapter of the Qur'an } \\ \text { Ummah } & \text { God consciousness } \\ \text { Zakat or Zakah } & \text { The holy book of Muslims } \\ & \text { The Muslim community } \\ \text { Compulsory charity }\end{array}$




\section{References}

Ahmed, Leila. 1992. Women and Gender in Islam. New Haven: Yale UP.

Ahmed, Nazeer. 2000. Islam in Global History: From the Death of Prophet Muhammed to the First World War. Chicago: Xlibris.

Akhter, Shamim. 2009. Faith and Philosophy of Islam. India: Kalpaz Publications.

Al-Bukhari, Muhammad. 846 CE. Sahih Bukhari. Translated by M. Muhsin Khan. Available online: www. searchtruth.com (accessed on 1 June 2014).

Alexander, Jonathan. 2008. Literacy, Sexuality, Pedagogy: Theory and Practice for Composition Studies. Logan: Utah State UP.

Ali, Shaheen Sardar, and Javaid Rehman. 2005. The Concept of Jihad in Islamic International Law. Journal of Conflict \& Security Law 10: 321-43.

Ali, Syed Ameer. 1891. The Life and Teachings of Mohammed: Or, The Spirit of Islam. London: W.H. Allen \& CO. LTD.

An-Nasa'i, Ahmad. n.d. Sunan an-Nasa'i. Available online: www.Sunnah.com (accessed on 20 May 2018).

Asfahani, Abu Nai'm. n.d. The Beauty of the Righteous and Ranks of the Elite. Translated by Muhammad Al-Akili. Damascus: Dar Al-Fikr.

At-Tahan, Mustafa. 1999. Perfect Muslim Character in the Modern World. Cairo: Al-Falah Foundation, Translation, Publishing, \& Distribution.

Bin Hassan, Ahmad Saiful Rijal. 2016. ISIS: Questions about Its Survival \& Ideology. Counter Terrorist Trends and Analyses 8: 4-8.

Brown, Jonathan. 2015. Misquoting Muhammad: The Challenge and Choices of Interpreting the Prophet's Legacy. London: Oneworld Publication.

Donner, Fred. 1986. The Formation of the Islamic State. Journal of the American Oriental Society 106: $283-96$. [CrossRef]

Esposito, John L, ed. 2003. The Oxford Dictionary of Islam. Oxford: Oxford Islamic Studies, Available online: www.oxfordislamicstudies.com (accessed on 20 May 2019).

Freedman, Paul. 2011. Islamic Conquests and Civil War. New Haven: Yale University.

Geissinger, Aisha. 2011. A'isha Bint Abi Bakr and Her Contributions to the Formation of the Islamic Tradition. Religion Compass 5: 37-49. [CrossRef]

Griffiths, Martin, ed. 2005. Encyclopedia of International Relations and Global Politics. New York: Routledge.

Hashmi, Sohail H. 2007. Cultivating a Liberal Islamic Ethos, Building an Islamic Civil Society. Journal of the Society of Christian Ethics 27: 3-16. [CrossRef]

Hazleton, Lesley, ed. 2010. On Reading the Quran. Talk at TED. New York: TED.

ISIS's Persecution of Religions. 2017. Counter Terrorism Project. Available online: www.counterterroism.com (accessed on 10 April 2019).

ISIS's Persecution of Women. 2017. Counter Terrorism Project. Available online: www.counterterroism.com (accessed on 10 April 2019).

Kamali, Mohammad Hashim. 1991. Principles of Islamic Jurisprudence. Cambridge: Islamic Texts Society.

Kausar, Sajila. 2017. Collective Ijtihad: History and Current Perspective. International Journal of Humanities $\mathcal{E}$ Social Science Studies III: 151-63.

Lynch, Paul, and Matthew Miller. 2017. Twenty-Five Years of Faith in Writing: Religion and Composition 1992-2017. Present Tense: A Journal of Rhetoric in Society 6: 1-195.

Madelung, Wilferd. 1997. The Succession to Muhammad: A study of the Early Caliphate. Cambridge: Cambridge UP.

Martin, Richard C. 2004. Minorities: Dhimmis. In Encyclopedia of Islam and the Muslim Word. Available online: encyclopedia.com (accessed on 19 September 2019).

Masood, Steven. n.d. The Concept of Ijtihad in the History of Islamic Jurisprudence. Dr. Steven Masood. Available online: www.stevenmasood.org (accessed on 12 May 2017).

McIntire, Suzanne, and William E. Burns. 2009. Speeches in World History. New York: Infobase Publications.

Muslim, Ibn Al-Hajjaj. 1330 CE. Sahih Muslim. Translated by Abd-al-Hamid Siddiqui. Sahih Muslim. Available online: www.SearchTruth.com (accessed on 13 June 2014).

Nasr, Seyyed Hossein. 2001. Islam: Religion, History, and Civilization. New York: HarperCollins.

Netton, Richard, ed. 2008. Encyclopedia of Islamic Civilization and Religion. Oxford: Routledge.

Omar, Irfan A. 2011. Keeping Shari'a and Reclaiming Jehad. Political Theory 12: 706-12. 
Sajoo, Amyn B. 1995. The Islamic Ethos and the Spirit of Humanism. International Journal of Politics, Culture, and Society 8: 579-96. [CrossRef]

Sardar, Ziauddin. n.d. Critical Thought and the Future of Islam. Oxford: Oxford Islamic Studies, Available online: www.oxfordislamicstudies.com (accessed on 11 April 2019).

Sowerwine, James E. 2009. Caliph and Caliphate. Oxford: Oxford Bibliographies, Available online: www. oxfordbibliographies.com (accessed on 15 January 2019).

Spivak, Gayatri Chakravorty. 1994. Can the Subaltern Speak? In Colonial Discourse and Post-Colonial Theory: A Reader. Edited by Patrick Williams and Laura Chrisman. New York: Colombia UP.

Stacey, Aisha. 2009. The Story of the Quran: Then, Today, and for all Time. The Religion of Islam. Available online: www.Islamreligion.com (accessed on 15 January 2018).

Stacey, Aisha. 2009. Uthman Ibn Affan: Generous and Pious. The Religion of Islam. Available online: www. Islamreligion.com (accessed on 21 January 2018).

Syed, Ibrahim. n.d. Social Security in Islam. Louisville: Islamic Research Foundation International, Inc.

Tahir-ul-Qadri, Muhammad. 2012. Constitutional Analysis of the Constitution of Madina: 63 Constitutional Articles. EBook. London: Minhaj Ul-Quran Publications.

Tahmaz, Abdulhamid Mahmud. 1999. Al Sayyidatu Aisha. Damascus: Daru'l Qalam.

The Holy Qur'an. 2000. Abdullah Yusuf Ali, trans. Hertfordshire: Wordsworth Editions Limited.

The Prophet of Islam Muhammad: A Biography and a Pictorial Guide. 2017. Kuwait: Osoul Global Center.

Townsend, Mark. 2018. The Core ISIS Manual that Twisted Islam to Legitimise Barbarity. The Guardian, May 12. Wirba, Asan Vernyuy. 2017. Leadership from an Islamic and Western Perspective. Oxford: Chartridge Books Oxford.

(C) 2019 by the author. Licensee MDPI, Basel, Switzerland. This article is an open access article distributed under the terms and conditions of the Creative Commons Attribution (CC BY) license (http://creativecommons.org/licenses/by/4.0/). 